\title{
Further investigation of the role of progesterone in the control of embryo transport in the mouse
}

\author{
K. L. Grieve, J. M. Henwood and K. E. Kendle
}

School of Pharmacy, Robert Gordon's Institute of Technology, Schoolhill, Aberdeen AB9 IFR, U.K.

\begin{abstract}
Summary. Combined ovariectomy and adrenalectomy retarded mouse embryo transport while either operation alone did not. Serum progesterone levels were reduced after ovariectomy and after the combined operation but detectable levels were still present on Day 4 following both procedures. Embryo transport was also retarded after administration of testosterone propionate. This effect was abolished by progesterone and was not mimicked by $5 \alpha$-dihydrotestosterone. From these results it is concluded that progesterone influences embryo transport and that androgenic effects are probably a result of antagonism of progesterone.
\end{abstract}

\section{Introduction}

Previous studies of the influence of progesterone on mouse embryo transport have shown that the rate of transport was essentially unaltered by ovariectomy or progesterone administration after ovulation, but was increased by preovulatory progesterone treatment (Kendle \& Lee, 1980). Further post-ovulatory administration of the antiprogestational steroids RMI 12,936 and R 2323 caused arrest or delay of transport and the effect of RMI 12,936 was abolished by exogenous progesterone. It was concluded that the transport process was triggered by progesterone and required continued progesterone activity at the tissue level for its maintenance. No data were given, however, to explain the difference between the effects of ovariectomy, which did not alter transport, and antiprogestational steroids, which caused retardation. It was suggested that ovariectomy might result in extra-ovarian progesterone secretion, probably by the adrenal gland. Other explanations could be that the elimination of progesterone after ovariectomy is sufficiently slow that adequate tissue levels persist during the transport phase or that the antiprogestational steroids are acting through a mechanism other than antiprogestational activity.

RMI 12,936 is known to be metabolized in rats to $7 \alpha$-methyl testosterone (Hardy, Kendle, Lawrie \& Omand, 1977; Taylor \& Kendle, 1978), and to exhibit marked androgenic properties (Bullock, Feil, Gupta, Demers \& Bardin, 1978), while androgens are known to disrupt embryo transport and cause retention of embryos in mice (Burdick, Emerson \& Whitney, 1940). It has not, however, been established whether this effect is mediated via androgen receptors. There is evidence to suggest a similarity between androgen and progesterone receptors. Some compounds may act as agonists or antagonists. For example, steroids of the 17-hydroxyprogesterone type are anti-androgenic (Neri \& Kassem, 1982) and most potent progestational steroids are substituted 19nor-testosterones.

The present study was undertaken to elucidate further the role of progesterone in the control of embryo transport. The hypotheses evaluated were (1) that ovariectomy alone does not result in immediate tissue deprivation of progesterone because there is adrenal progesterone secretion or slow progesterone elimination and (2) that antiprogestational steroid effects might be mediated via androgen receptors. 


\section{Materials and Methods}

Albino mice of the RGIT/SLAC strain were housed under constant conditions of $9 \mathrm{~h}$ light $(09: 00-$ 18:00 h) and $21 \pm 1{ }^{\circ} \mathrm{C}$. Water and Oxoid pasteurised breeding diet for rats and mice were freely available. Mature virgin females, 6-12 weeks old, were paired with mature males and were examined each morning for the presence of a vaginal plug, which was taken as evidence of successful copulation. The day on which a plug was found was defined as Day 1 of pregnancy.

Ovariectomy and/or adrenalectomy, or appropriate sham procedures were carried out through bilateral flank incisions, under pentobarbitone anaesthesia $(60 \mathrm{mg} / \mathrm{kg}$ i.v.) between 09:30 and 11:00 h on Day 1 of pregnancy.

Steroids (testosterone propionate, $5 \alpha$-dihydrotestosterone and progesterone, purchased from Sigma Chemical Co., Poole, Dorset, U.K.), were suspended in water containing $0 \cdot 25 \%(\mathrm{w} / \mathrm{v})$ sodium carboxy-methylcellulose and $1 \%(\mathrm{v} / \mathrm{v})$ Tween 80 and were administered subcutaneously in a dose volume of $0.1 \mathrm{ml}$ at $09: 30 \mathrm{~h}$ on the days of pregnancy reported in 'Results'.

When appropriate, blood samples were taken by cardiac puncture under ether anaesthesia, and the serum progesterone concentrations were measured with a commercially available $\left[{ }^{3} \mathrm{H}\right]$ progesterone radioimmunoassay kit (Radioassay Systems Laboratories Inc., Carson, CA, U.S.A.). The cross-reactivity for the progesterone antiserum was stated by the manufacturer to be $2 \cdot 1 \%$ for desoxycorticosterone, $0.8 \%$ for pregnenolone, $0.3 \%$ for 20 -dihydroprogesterone, and $<0.1 \%$ for testosterone, androstenedione, $5 \alpha$-dihydrotestosterone, oestradiol, oestrone and oestriol.

All animals were killed at $12: 00 \mathrm{~h}$ on the day of pregnancy stated in 'Results' and when appropriate the mean percentage oviduct traversed was calculated as previously described (Kendle \& Bennett, 1969). Appropriate groups were compared statistically using the Welch test (Welch, 1947). Probability values of $<0.05$ were considered significant. Mean numbers of embryos were calculated for each group and analysed statistically. Since none was significantly different from controls these data are not reported.

\section{Results}

Ovariectomy or adrenalectomy did not alter the rate of embryo transport when compared to that in appropriate sham-operated control animals. Ovariectomy combined with adrenalectomy resulted in significant delay in transport $(P<0.05)$, which could be abolished by daily administration of 0.8 mg progesterone (Table 1).

Serum progesterone concentrations (mean \pm s.e.m.) in intact, adrenalectomized, ovariectomized, and ovariectomized-adrenalectomized animals $(N)$ on Day 4 were $56.4 \pm 7 \cdot 6(N=6), 39 \cdot 6$

Table 1. The effect of ovariectomy, adrenalectomy or ovariectomy and adrenalectomy on tubal transport of mouse embryos, in comparison to that in appropriate sham-operated controls, killed on Day 4 of pregnancy

\begin{tabular}{lccc}
\hline \multicolumn{1}{c}{ Surgical procedure } & Real & Sham & $\begin{array}{c}\text { Statistical } \\
\text { evaluation }\end{array}$ \\
\hline Adrenalectomy & $91.4 \pm 5.14$ & $98.7 \pm 0.94$ & N.S. \\
Ovariectomy & $88.2 \pm 3.56$ & $89.2 \pm 2.72$ & N.S. \\
Ovariectomy-adrenalectomy & $83.6 \pm 5.65$ & $98.4 \pm 1.04$ & $P<0.05$ \\
Ovariectomy-adrenalectomy with & $99.1 \pm 0.93$ & & \\
$\quad 0.8$ mg progesterone/day & & & \\
\hline
\end{tabular}

Figures are mean $\%$ oviduct traversed \pm s.e.m. ( $n=10$ oviducts in all groups). 
Table 2. The effect on tubal embryo transport in mice killed on Day 4 of daily administration of steroids from Days 1 to 4

\begin{tabular}{|c|c|c|c|}
\hline Steroid & $\begin{array}{l}\text { Daily dose } \\
\text { (mg) }\end{array}$ & $\begin{array}{l}\text { Mean } \pm \text { s.e.m. } \\
\text { transport }(\%) \\
\quad(n=10)\end{array}$ & $\begin{array}{c}\text { Comparison } \\
\text { to control }\end{array}$ \\
\hline Control & 0 & $98 \cdot 0 \pm 1 \cdot 0$ & \\
\hline Testosterone propionate & 1.0 & $56 \cdot 0 \pm 9 \cdot 5$ & $P<0.001$ \\
\hline Testosterone propionate & $5 \cdot 0$ & $48 \cdot 8 \pm 10 \cdot 7$ & $P<0.001$ \\
\hline Testosterone propionate + progesterone & $1-0+0 \cdot 8$ & $94 \cdot 3 \pm 1 \cdot 0$ & N.S. \\
\hline Testosterone propionate + progesterone & $5.0+0.8$ & $61 \cdot 2 \pm 12 \cdot 1$ & $P<0.05$ \\
\hline Dihydrotestosterone & 0.6 & $97 \cdot 2 \pm 1 \cdot 1$ & N.S. \\
\hline Dihydrotestosterone & $1 \cdot 2$ & $89 \cdot 8 \pm 8 \cdot 0$ & N.S. \\
\hline
\end{tabular}

$\pm 4.7(\mathrm{~N}=8), 10.9 \pm 4.0(\mathrm{~N}=8)$ and $7 \cdot 0 \pm 2 \cdot 0(\mathrm{~N}=8) \mathrm{ng} / \mathrm{ml}$, respectively. Ovariectomy and ovarectomy-adrenalectomy caused a significant reduction compared with intact controls $(P<$ 0.005 ) while adrenalectomy did not. The group means of the ovariectomized and ovariectomizedadrenalectomized animals were, however significantly greater than zero $(P<0.05$ and $P<0.005)$ and were not significantly different from each other. The adrenalectomized group mean was not significantly different from that of the intact control (Welch test).

Daily administration, from Day 1 to 4 , of 1 or $5 \mathrm{mg}$ testosterone propionate resulted in delay in embryo transport when compared to that in vehicle-treated controls. The effect of $1 \mathrm{mg}$ testosterone propionate, but not $5 \mathrm{mg}$, could be abolished by concurrent administration of $0.8 \mathrm{mg}$ progesterone. $5 \alpha$-Dihydrotestosterone, $0.6 \mathrm{mg}$ or $1.2 \mathrm{mg}$ daily on each of Days 1 to 4 , was without significant effect (Table 2).

Two further experiments were carried out to determine whether testosterone effects differed from those of oestradiol. Treatment with $1 \mathrm{mg}$ testosterone propionate on each of Days 3 and 4 resulted in a significant delay $(P<0.001)$ which was abolished by concurrent administration of $0.8 \mathrm{mg}$ progesterone. The mean \pm s.e.m. percentages of the oviduct traversed on Day 4 were $99.1 \pm$ $0 \cdot 1(n=20) ; 92 \cdot 2 \pm 1 \cdot 2(n=10)$ and $98.4 \pm 0.4(n=10)$ in control, testosterone and testosterone plus progesterone groups, respectively.

Administration of a single dose of steroid early on Day 1 resulted in no significant difference in mean percentage oviduct traversed, measured on Day 4 , for 1 or $5 \mathrm{mg}$ testosterone propionate or $1 \cdot 2$ mg $5 \alpha$-dihydrotestosterone when compared to that in untreated controls. The respective mean \pm s.e.m. percentages of the oviduct traversed in these groups were $98.6 \pm 1.4(n=10) ; 86.0 \pm 8.2(n$ $=10) ; 99.1 \pm 0.5(n=10)$ and $99.9 \pm 0 \cdot 1(n=20)$.

\section{Discussion}

Previous work (Kendle \& Lee, 1980) has shown that post-ovulatory ovariectomy in mice does not affect tubal embryo transport. This is confirmed in the present study, but extended to show that ovariectomy combined with adrenalectomy results in significant retardation, which is abolished by concurrent administration of progesterone. Similar procedures have been carried out in rats by Forcellado, Morales, Vera, Quijada \& Croxatto (1982) who showed a significant retardation and early loss of embryos in ovariectomized and ovariectomized-adrenalectomized animals. The combined effect of ovariectomy and adrenalectomy was also abolished by concurrent administration of progesterone by subcutaneous implantation. Forcellado et al. (1982) also reported that these effects were accompanied by low levels of serum progesterone $(<5 \mathrm{ng} / \mathrm{ml})$ while normal 
transport occurred when progesterone was higher $(\sim 10-50 \mathrm{ng} / \mathrm{ml})$ from Days 2 to 5 of pregnancy. The present results indicate that a low but significant amount of circulating progesterone is still present 4 days after surgery in ovariectomized and ovariectomizedadrenalectomized animals, and it is suggested that this progesterone is sufficient to maintain embryo transport in ovariectomized animals, while it is insufficient in ovariectomizedadrenalectomized animals. Although the mean progesterone concentrations in these groups are not significantly different, they are lower in the ovariectomized-adrenalectomized group. Similarly, the progesterone concentration in adrenalectomized animals is lower than in intact controls although the difference is not statistically significant. These data do suggest that the adrenal gland may be making a small contribution to progesterone concentrations but this possibility requires further investigation.

The present results also confirm the delaying effect of exogenous testosterone reported by Burdick et al. (1940). However, $5 \alpha$-dihydrotestosterone at doses with equivalent androgenic activity was without significant effect. Since, for the rat prostate at least, it has been shown that the active species at the level of the androgen receptor is $5 \alpha$-dihydrotestosterone formed in situ from testosterone by the action of $5 \alpha$-reductase (Tenniswood, Bird \& Clark, 1982), it seems unlikely that the effect of testosterone propionate on egg transport is via androgen receptors.

It is possible that the effects seen are due to biotransformation of testosterone to oestradiol, which is known to disrupt embryo transport. However, the effect of testosterone propionate is not manifest on Day 4 after a single administration on Day 1, as is the case for oestradiol (Humphrey, 1968), and testosterone propionate administered on Days 3 and 4 results in a delay, while oestradiol administration after embryos have entered the isthmus results in rapid expulsion and loss of embryos (Lee, 1979). The delay induced by $1 \mathrm{mg}$ testosterone propionate administered on Days 1-4 or Days 3 and 4 is abolished by concurrent administration of progesterone, whereas the effects of oestradiol have been reported to be unaffected by concurrent progesterone administration (Humphrey, 1968).

The results therefore suggest that the delay caused by administration of testosterone is antiprogestational in nature. As suggested in the 'Introduction', it is likely that this antagonism is at the receptor level but other possibilities must also be considered such as the effects of androgen on progesterone secretion. Further investigations will therefore be carried out including progesterone assays in androgen-treated animals.

K.L.G. is in receipt of a S.E.R.C. Post-graduate Award.

\section{References}

Bullock, L.P., Feil, P.D., Gupta, C., Demers, L.M. \& Bardin, C.W. (1978) Androgenic effects of the antiprogestagen RMI 12,936. J. Reprod. Fert. 52, 365 371 .

Burdick, H.O., Emerson, B.B. \& Whitney, R. (1940) Effects of testosterone propionate on pregnancy and on passage of ova through the oviducts of mice. Endocrinology 26, 1081-1086.

Forcellado, M.L., Morales, P., Vera, R., Quijada, S. \& Croxatto, H.B. (1982) Role of ovarian and adrenal progesterone in the regulation of ovum transport in pregnant rats. Biol. Reprod. 27, 1033-1041.

Hardy, D.G., Kendle, K.E., Lawrie, M.R. \& Omand, H.E. (1977) The effect of RMI 12,936, a synthetic antiprogestational steroid, on ovarian steroidogenesis in the rat. J. Reprod. Fert. 49, 231-235.
Humphrey, K.W. (1968) The effects of oestradiol 3,17 beta on tubal transport in the laboratory mouse. $J$. Endocr. 42, 17-26.

Kendle, K.E. \& Bennett, J.P. (1969) Studies upon the mechanism of reserpine-induced arrest of egg transport in the mouse oviduct. J. Reprod. Fert. 20, 429-434.

Kendle, K.E. \& Lee, B. (1980) Investigation of the influence of progesterone on mouse transport by using anti-progestational steroids. J. Reprod. Fert. 58, 253-258.

Lee, B. (1979) Investigation of the role of smooth muscle function in egg transport in the mouse oviduct. Ph.D. thesis, C.N.A.A.

Neri, R. \& Kassem, N. (1982) Pharmacological and clinical effects of antiandrogens. In Hormone 
Antagonists, pp. 247-268. Ed. M. K. Agarwal. Walter de Gruyter, Berlin.

Taylor, R.B. \& Kendle, K.E. (1978) Use of HPLC to determine the effect of 17-hydroxy-7 $\alpha$ methylandrost-5-en-3-one (RMI 12,936) on production of progesterone by rat ovarian homogenate. Acta endocr., Copenh. 88, 157-163.
Tenniswood, M., Bird, C.E. \& Clark, A.F. (1982) The role of androgen metabolism in the control of androgen action in the rat prostate. Molec. cell. Endocr. 27, 89 96.

Welch, B.L. (1947) The generalisation of "Students" problem when several different population variances are involved. Biometrika 34, 28-34.

Received 30 May 1984 